\title{
Undefined lands: A review of their role as an underexplored resource of landscape
}

\author{
Maryam Naghibi, Mohsen Faizi, Ahmad Ekhlassi \\ School of Architecture and Environmental Design, \\ Iran University of Science and Technology (IUST), Iran
}

\begin{abstract}
Landscape areas have spatial discontinuities, such as vacant land and leftover spaces. Undefined lands present a compelling area for landscape research, aesthetical experience, and development of cities which discuss irregular and unexpected aspects in landscape settings. Having lacked a formal definition of undefined land, this study aims at proposing keywords of undefined lands, a comprehensive review of knowledge, and definition. In order to promote new aspects of such spaces in the future research, the study conducts a systematic analysis of 65 peer-reviewed papers for their temporal trends, locations, methods, key authors, and commonly studied aspects. Results show the production of vacancy and the temporary use of undefined lands as an opportunity, and a flexible method of regeneration. An increase in publications over the past 30 years demonstrates that leftover space is an evolving subject. Although socio-ecological aspects are the most effective, serious gaps are mentioned in the literature considering aesthetical and ecological qualities in leftover spaces formed by visual, sensorial (hearing, touch, smell, taste), and cognitive perception. These gaps in the literature suggest that it is important to understand the potential effects of repurposing citizen's ideas about interventions in which to use leftover spaces. Having identified the knowledge gaps, undefined lands are suggested as a significant sub-discipline in landscape research.
\end{abstract}

Keywords: vacant land, landscape, leftover space, brownfield, lost space

\section{Introduction}

Having considered cities from the landscape perspective, they are highly fragmented lands that consist of built and vacant areas, developed and derelict buildings, and infrastructure [71]. Over the past few decades, urban shrinking, decentralization, population decline in cities and deindustrialization have created a large number of residual spaces [23]. While vacant lands associated with the slump, crime and unsightly spaces $[1 ; 2 ; 7 ; 19]$, they can be used as an ecological, economic and social resource [3]. For the restoration of cities, space generation and multiple of other functions, Lefebvre presents a bottom-up solution, and indicates the role of the inhabitants [40]. Moreover, Wikströms carries out research concerning the meanings of vacant lands and their function in landscapes [85; 86], concerning public space for transgressing the boundaries in a segregated city as a part of an interdisciplinary project [87].

A large body of literature recognizes that negative connotations of residual spaces can overshadow positive aspects $[16 ; 17 ; 18 ; 33 ; 41 ; 50 ; 52 ; 57 ; 60 ; 82 ; 89]$. In fact, studies show that vacancy can be found as a valuable resource for local communities, economies, and environments $[7 ; 38]$. Therefore, there has been an increase in transforming these informal spaces into formal spaces in the landscape $[8 ; 71]$. Such transformations could improve sustainability, by increasing the balance among different aspects of social well-being, environmental protection, and economic development (Wu, 2010) and provide opportunities for the redevelopment of urban activities like employment and housing [75].
As researchers have seemingly neglected, undefined lands elicit many questions. Could such informal spaces be viewed as an ephemeral and temporary space? How can vacant lands be of productive use? How can these informal spaces be defined globally? How does the literature view their characteristics in the landscape? What Kind of trends exist within the literature (temporal trends, spatial patterns, methods used, key authors)? How can the voids become productive building blocks for the city? What causes are associated with changes in vacant land supply? To answer these questions, this study advances a concise review of 65 peer-reviewed research papers, on what we call 'undefined land', a particular type of informal land.

\section{Liminality and informality: defining undefined land}

In general, these areas are not considered as landscapes. These alternative areas may include a sunken plaza, parking lots, flower-rich vacant lot, an overgrown roadside edge. At a larger scale, they may be found as abandoned structures or industrial sites [17]. They are not descriptive but constitutive, meaning they do not describe a space that is a 'dead zone', but they produce it [13].

During the Modern era, standardized designs, the focus on the consumption of commodities and primary living conditions distanced users from communal interaction. According to Trancik [82], lost space was the result of designing isolated and mass-produced spaces when the standardized designs trumped concerns for user values and community, eroding traditional forms of urban space. 


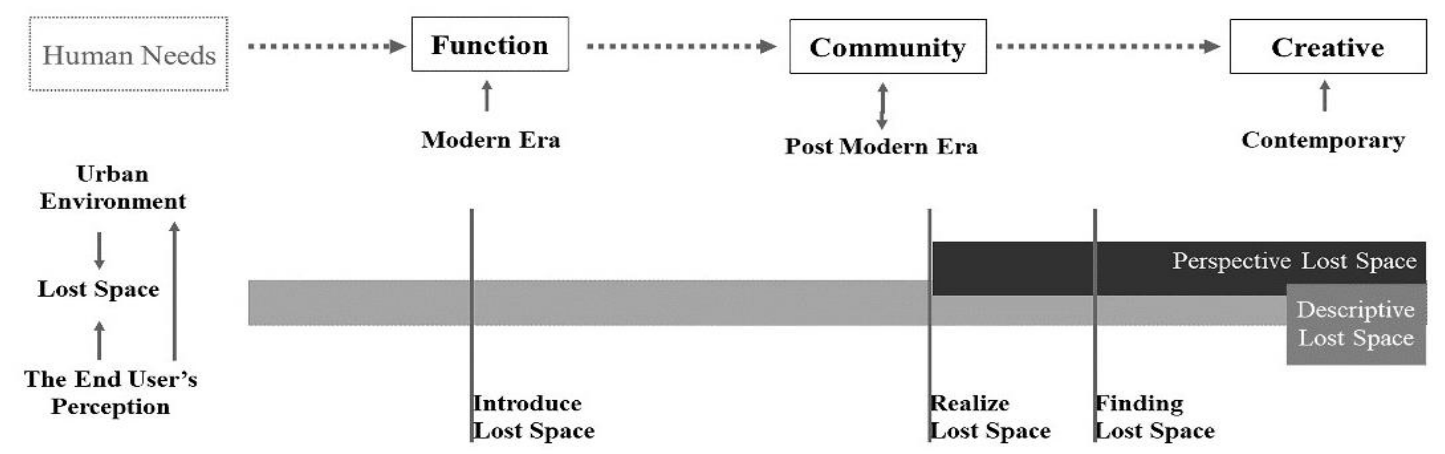

Fig. 1. Definitions of undefined lands - Source: Adopted form [42]

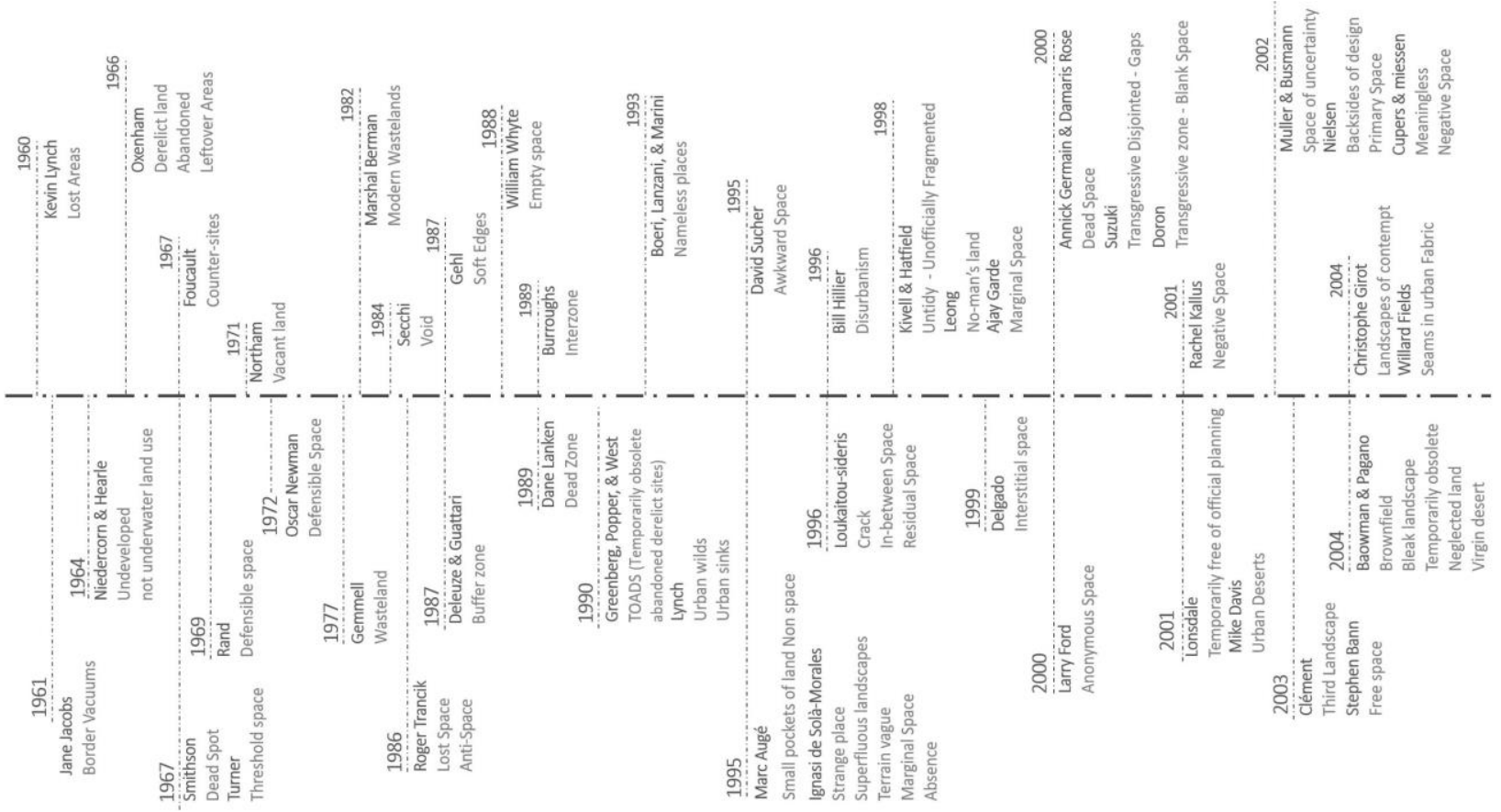

Fig. 2a. Terms used to refer to undefined lands [created by authors, 2019]

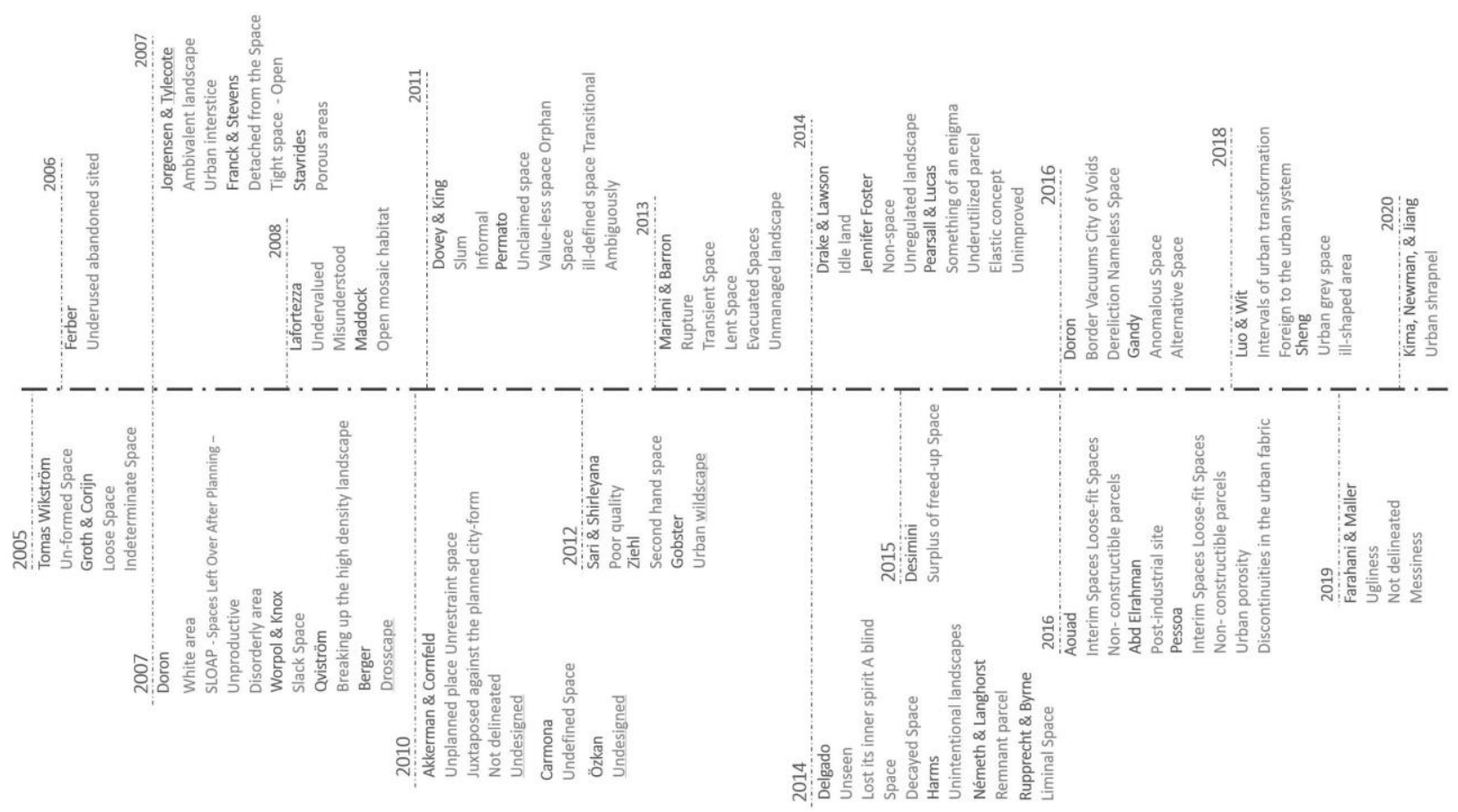

Fig. 2b. Terms used to refer to undefined lands [created by authors, 2019] 


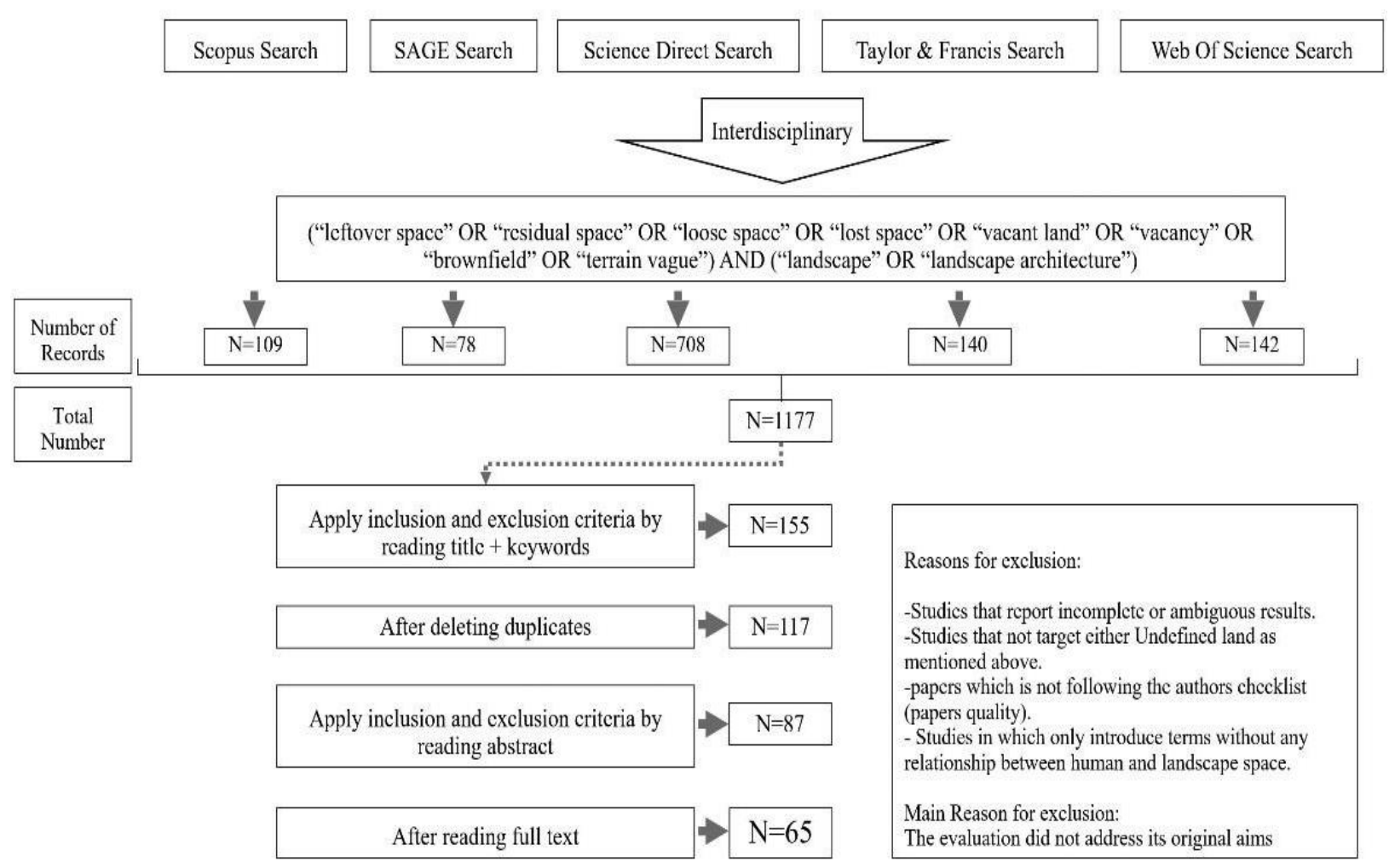

Fig. 3. The automatic search process and number of selected papers in each stage.

* Due to the literature, the most common keywords were selected for automatic search [created by authors, 2019]

According to Figure 2a, 2b, vacant lands and abandoned structures are widely acknowledged with different definitions and prescriptions because there is no specific accepted definition [7]. Therefore, this section has been conducted trying to include almost all related literature to undefined lands. Krier [29] argues that the spaces in any urban environment could be considered as urban spaces. Also, according to Trancik [82], 'Space becomes place when it is given a contextual meaning derived from cultural or regional content' (1986). What this implies is that when a space is deprived of value and meaning, it becomes lost. Accordingly, what is a necessity is to present the concept of undefined space and its aftermath, which is reflected in the landscape. So far, various reviews have been conducted trying to include almost all keywords of undefined spaces in landscape architecture and to be more explicit to summarize the theories expressed over time. Figure 2, adapted from Fields [14] illustrates the theorists, the years of publications, along with the theories underpinning their research.

\section{Materials and Methods}

The existing systematic review is conducted in accordance with Pickering and Byrne's [66] approach. Since the result of the reviewed literature is not used for future statistical analysis, this method varies greatly from a classic meta-analysis. Yet rather relevant information extracted from published papers is used to explore geographic, methodological, and theoretical aspects in the literature [66]. To investigate the terms which are fully illustrated in Figure 2, the authors conducted a study and found out the most relevant terms. The selected search terms seem to be more general and they were mostly used in the first phase of the study. The search terms were used to find matches in article titles, keywords, and abstracts during an automatic search in electronic data sources. As indicated by the guidelines [30], the accompanying techniques were utilized to create the most applicable automatic search terms.

Having combined both the methodological search and deletion of duplicates, 65 papers were checked. Gibbs [20] mentioned the studies conducted, based on a qualitative paradigm through an analytical process. The articles were analyzed from the viewpoint of the case studies, focus areas, research methods, and common studied aspects.

According to Figure 2, this study sought to have a time limitation on the search (from 1960) and selected the research papers that were expressly targeting undefined land to further potentially related publications that were not returned in the databases. To be selected for the process of analysis, research papers had to follow one of the two inclusion criteria: (1) aim either terms used to refer undefined lands or (2) inquire about a relationship between human and landscape space. 


\section{Results and Discussion}

Having taken the above mentioned steps, followed by the deletion of duplicates, 65 selected papers were gathered among 28 journals. As it is shown in Figure 4, the most original research papers were published in Urban Forestry \& Urban Greening (9), followed by Landscape and Urban Planning (9), Cities (8), and Landscape Research (8). This suggests that there is a widely recognized interest in this topic in various types of journals.

\section{Main aspects studied}

As presented in Figure 5, a variety of aspects can be detected over the systematic review. Additionally, having examined the trends in the literature review, the main idea, and the papers' findings are discussed. The selected original research papers targeted a variety of aspects, such as ecological (20 papers, $30.7 \%$ ), social (18 papers, $27.6 \%$ ), economic (15 papers, $23 \%$ ), and shrinkage and gentrification (15 papers, $23 \%$ ) being the most prevalent, respectively (Figure 5). Multiple aspects of undefined lands were investigated in most selected papers. Pickett, Cadenasso, and Grove [68] examined a promising new tool for promoting the integrating between ecological and socio-economic aspects.

Having considered heterogeneous patches which have complex combinations in landscape, Jacobs [27], Machlis [46; 65], Gottdiener and Hutchison [22], Pickett et al. [67], Holling [26], Walker et al. [84], Folke [15], Cadenasso [9], Pickett et al. [69], determined a definitive relationship between ecological and social aspects of undefined lands across the urban landscape. Moreover, the rethinking of the unstructured landscape such as community gardens, vacant lots, informal parks and edges of freeways that could sustain socio-ecological interaction [37], drew Sutton and Kemp [79] to demonstrate that undefined lands could generate from 'places of inequities' to 'places of transformation'. Therefore, when it comes to revitalizing communities and landscape change in undefined lands, previous studies suggest a bottom-up approach in contrast to traditional top-down approaches.

Most socio-economic variables seemed to be less influential in shrinking cities than in growing cities [39] and as shrinking cities have experienced depopulation, resulting in a remarkable economic crisis [24], many studies seek to consider multiple aspects in their research. Easier land assembly and lower development costs based on existing infrastructure [54] are the most critical factors in investigating economic aspects. However, opportunities to redevelop vacant land by improving its ecological and social value $[25 ; 28 ; 36$; $38 ; 54 ; 72 ; 73 ; 74 ; 90]$ is the most common aspect in this systematic review. Therefore, there are several embracing issues, brought by multidisciplinary views on leftover projects.

According to Loures [44], the creation of multifunctional areas in undefined lands could be the chief concern in the redevelopment process. In this regard,

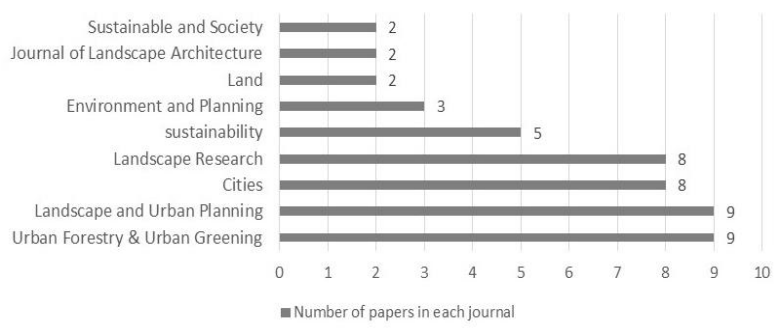

Fig. 4. Journals containing most undefined land papers [created by authors, 2019]

being aware of the community perceptions to inform landscape regeneration projects and to consider the social, economic, environmental, and cultural functions are essential. However, through assessing the vacant lot uses, the physical indicators (size, shape, location) and socio-ecological characteristics, planners may be able to underpin the resilience approach and sustainable concepts in undefined landscapes [38]. While the discovery of ways became necessary to develop the urban environment in a more sustainable way, our view of intervention is near-sighted [8]. Urban decline offers great potential and can become the embodiment for urban green space and ecosystem services rather than being abandoned relics of failure.

To intervene in undefined lands and increase the liveability of urban neighborhoods, it is essential to fuse the fractured literature of how such spaces are used or the reasons why they are not used [50]. Although some policies with top-down strategies showed that the social value of these vacant land projects are not relevant to the sense of residential environment, it seems feasible that tactical urbanism, as an effective treatment for redesigning the unused lands, could transform these spaces into a meaningful place with a sense of community [4].

For instance, the literature suggests apart from other frameworks, to understand landscape aesthetics, the context of informal urban lands and their connection to a more extensive system of social aspects are crucial for the perception of the value of leftover spaces programs [78].

The significance of this analysis is that it sheds light on a new perspective of vacancy as a substantial socioecological resource, which can enhance health and promote quality of life for communities [31]. Moreover, studies on urban structure, function, and value can promote decision-making and, consequently, improve environmental issues and human health [34].

\section{Temporal trends of the selected papers}

As illustrated in Figure 6, the number of original research papers has significantly risen over the last 30 years, with over $86 \%$ of papers published since 2012 . Considering the potential for recreation, the undefined land has aroused considerable interest in 1986 [82]. A reason for the increasing interest may be the ongoing urbanization, shrinking cities $[47 ; 54 ; 73]$, the continuity of the place [45; 90], and social and ecological perspectives $[43 ; 80]$. 


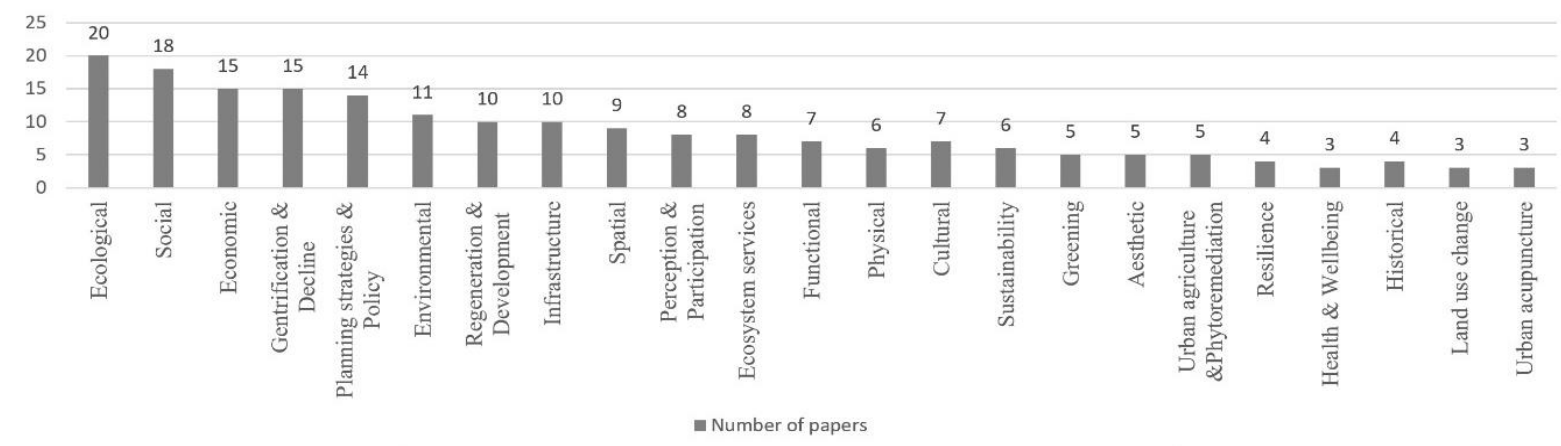

Fig. 5. The issues that have been an emphasis on various different papers [created by authors, 2019]

\section{Geographical patterns of the selected papers}

Interestingly, the geographic distribution of researchers around the world shows that the USA (35 papers, 53.8\%), has the highest number of researches around the world. Afterwards, the UK (9 papers, $13.8 \%$ ), Canada (4 papers, $6.1 \%$ ), Japan ( 3 papers, $4.6 \%$ ), and Germany ( 3 papers, $4.6 \%$ ) are the most cited.

\section{Undefined land type}

Based on the terms used in the title, abstract and keywords, the distribution of the selected research papers shows a clear bias in favour of vacant land (33 papers, $50.7 \%$ ) followed by all vacant land, vacancy and vacant lots (51 papers, $78.4 \%)$ and brownfield (16 papers, $24.6 \%$ ). The enormous number of selected papers may be due to the use of several types of keywords in general, but there is also a focus on one or two specific types. Moreover, these 65 papers had hardly compared different terms used. The scarcity of literature on the demolished, unintentional landscape, residual nature, and lost space keywords are considerable.

\section{Types of papers by their Methods}

As it is shown in Figure 8, the most common method was case study (27 papers, $41.5 \%$ ), followed by descriptive - interpretive (15 papers, $23 \%$ ), and literature review (15 papers, $23 \%$ ). Although the case study method is used extensively, there appears to be no accepted systematic case study method used per se. This means that researchers usually combine the case study method with methods such as literature review or certain statistical analysis like GIS. The reasons for the popularity of surveys may be due to the flexibility of collecting qualitative, quantitative data. Based on the indepth analysis, as illustrated in Figure 8, authors used different methods.

Many researchers used mixed methods, and Figure 8 indicates that questionnaire-based surveys were favoured in many studies $[5 ; 10 ; 44 ; 78 ; 81]$. According to Rupprecht and Byrne [71], the GIS-based method was not a common research method for investigating informal green spaces; however this systematic review reveals an increase in papers with GIS-based methods (7 papers, $10.7 \%$ ) used for analysing the case studies.

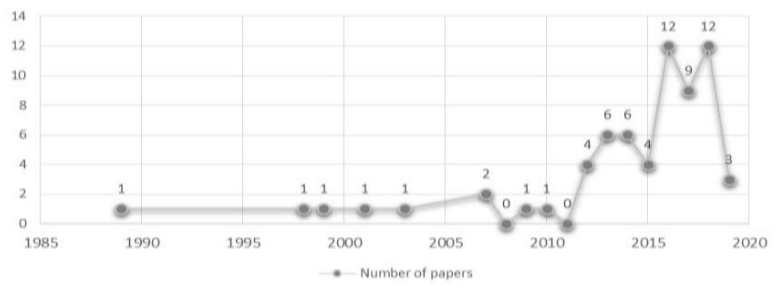

Fig. 6. Publication history of papers on undefined lands [created by authors, 2019]

Likewise, papers often combined interviews (7 papers, $10.7 \%$ ) with observations or questionnaires. Behaviour mapping (1 paper, $1.5 \%$ ), land allocation (MOLA) (1 paper, $1.5 \%$ ), Decision support systems (DSS) (1 paper, $1.5 \%$ ), and photography (1 paper, $1.5 \%$ ) are still comparatively rare.

\section{The first and key authors of the selected papers}

Some researchers have contributed to multiple original research papers. Newman, has analysed vacant land trends by region and city-type [55], designed with considering specific conditions such as using high ecological potential [59], structural connectivity of the landscape [56] and explored the possible interconnections [58], the importance of corridors and small-scale green spaces [56], urban elasticity [55] and transformations of physical change $[57 ; 58 ; 60]$.

Kim investigated gaps in knowledge about vacant land and properties which can be integrated with other green infrastructure [31], potential redevelopment of the vacant land [32], energy costs and structural value of the trees $[33 ; 34]$ and also expanded a comprehensive typology for introducing and perception of the potential of informal spaces as a part of urban landscape space [35].

Pallagst studied how manufacturing was affected by industrial transformation [62], green infrastructure development, and focusing on rightsizing [62]. Németh discussed the urban decline and community benefits [53], and presented the cases that could have temporary and short-time, transformational, flexible, dynamic and experimental responses to undefined lands [54]. Although the influence of industry on creating voids in the urban structure is invaluable, Unt introduced these places and evaluates the magnitude of the impact of small design interventions as urban acupuncture, on the activities carried out by the users [83]. 


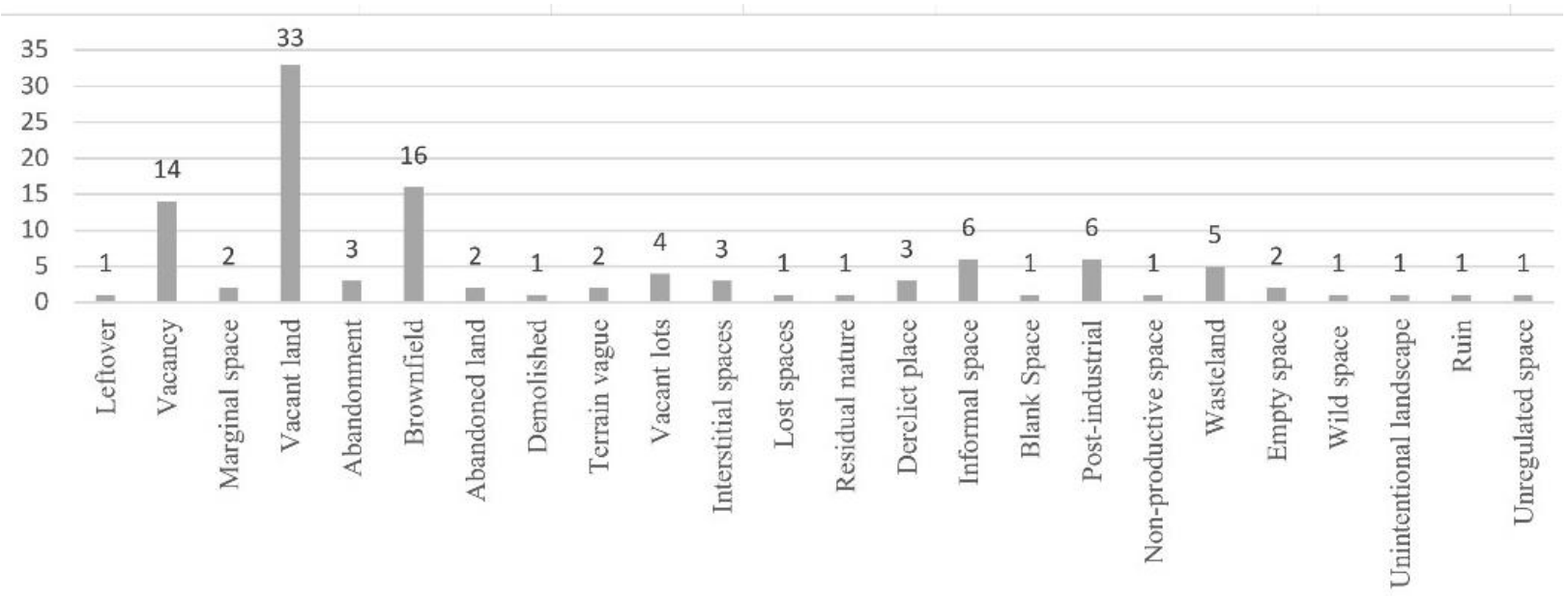

Number of papers

Fig. 7. Distribution of papers by targeted undefined lands type.

*Number of papers does not add up to 65 as papers may use more than one keywords [created by authors, 2019]

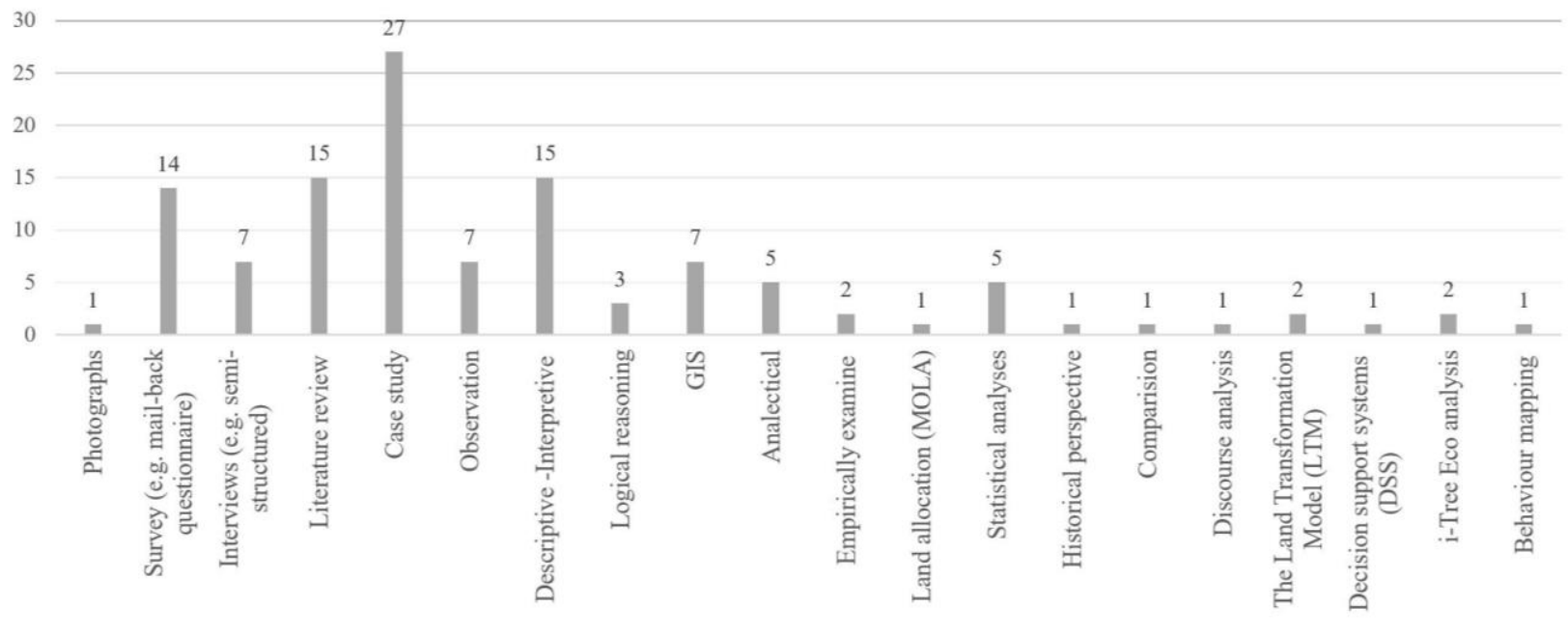

= Number of papers

Fig. 8. Methods used in papers on undefined lands.

*Number of papers does not add up to 65 as papers may use more than one method [created by authors, 2019]

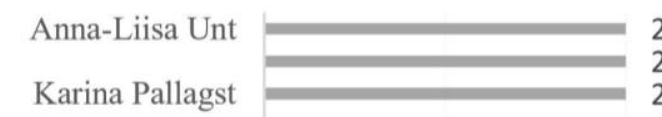

2

2

Galen D. Newman

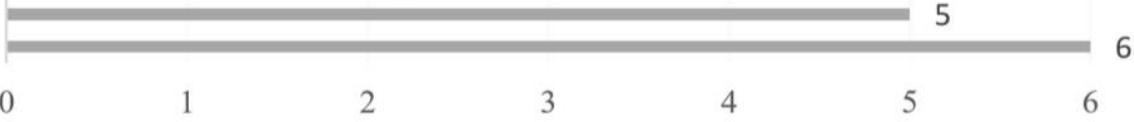

Number of papers by each author

Fig. 9. Authors publications of papers on undefined lands [created by authors, 2019]

\section{Geographical gap}

About 28 papers mentioned in the studies were conducted based on a case study method to investigate regions and cities all over the world. The geographic distribution of case studies illustrates a clear bias in favour of the USA (28 papers, $43 \%$ ), followed by Germany (4 papers, $6.1 \%$ ), Japan (3 papers, $4.61 \%$ ) and papers that investigated multiple cases (3 papers, $4.61 \%)$. Although 8 papers $(12.3 \%)$ did not mention any cases; so far, numerous studies were conducted by analysing different cases (57 papers, $87.6 \%$ ). However, they do not seem to be sufficient in geographical distribution, and papers from countries such as China with numerous studies, are significantly rare.

\section{Positive or / and negative}

While many assumptions are based on inherent negative aspects of vacancy and that vacant lots symbolize shrinking cities, urban decay or urban problems $[51 ; 55 ; 76 ; 88]$, this systematic review demonstrates that undefined land can provide alternative spaces for small interactions [81] as a long-term strategy or temporary process [48], also, areas for redeveloping 
the site, extensive growth in planning's paradigm $[24 ; 62]$, and an opportunity for communities to reclaim and revitalize their neighborhoods [63].

This study suggests that undefined lands appear to play an important role in landscape change, with a complex and sometimes contradictory process. Moreover, some interdisciplinary processes such as biodiversity guidelines in undefined land restoration provides a remedy resulting in considerably improved outcomes [64]. As defining the restoration is a critical component, the land is considered as the first stage of the physical process [3]. The perceived vacancy of undefined lands can be negatively interpreted as crack and dereliction [70].

This systematic literature emphasizes on redeveloping vacant land as a special opportunity to regulate shrinking cities in whether it occurred in the past or concerning future challenges. What it implies is that urban agriculture and green infrastructure might facilitate landscape spaces. As shrinking cities could be viewed as laboratories for experimenting with new frameworks of planning under crises and changing conditions [62], having been utilized more effectively, urban leftover spaces can supplement different types of open spaces for residents.

In shrinking cities with large amounts of undefined land, it is necessary to develop city-scale strategies $[11 ; 21]$. Before undefined lands can be occupied, they must be designed and constructed. This attention has tended to be affirmative; the temporary approach is a successful activator for urban voids [12], which are considered unutilized. In this concept, the temporary use of undefined lands, with their temporal and spatial fluctuations, should be analysed in the urban development process [49] as an opportunity for regeneration and renewal $[6 ; 77]$. On the other hand, cities with large numbers of undefined lands need more restructuring rather than the temporary approach. Temporary functions as well as a programmatic overlay can activate the vacant land and articulate them with the urban context as a catalyst for places of disinvestment [12].

\section{Directions for future research}

In addition to including various types of undefined lands, future studies should attract a variety of research methods. Ethnographic methods have only been used in very few cases. As Nijhuis exemplifies the potential of GIS as a tool for enriching the analytical framework in landscape [61], it may provide a valuable starting point for undefined global initiatives.

In order to use an interdisciplinary approach to assess lost spaces restoration and pose recommendations for future projects, it is necessary to synthesize mixed methods. Mixed methods also may provide new insights such as understanding resident's interaction with informal spaces, perception of community in defining these leftover spaces, and investigating transformational opportunities in landscape from a multidisciplinary perspective.

The research indicates the limitations of comparison of international case studies. The importance of these gaps is because of various types of spaces in each region, especially the variation in different cultural contexts. There is a requirement for further focus on cross-cultural research. So far, numerous studies have been conducted analyzing different cases; nevertheless, few studies have been conducted in undefined spaces in Asia, South America, and Africa. We could recognize that the scarcity of research papers in these regions could be attributed to being limited to English as the language used for this review.

In future studies, the socio-economic and physical characteristics of each parcel should be considered in order to reach an effective management strategy which is not only evidence-based and also requires long-term progress.

Otherwise, the process of regeneration is led to vague ideas in landscape planning [56].

\section{Conclusion}

To understand the role of leftover spaces in the landscape, this review has systematically analysed English literature on a group of quasi-public spaces termed 'undefined spaces. An increase in publications over the last 30 years demonstrates leftover space as an evolving subject in landscape research. Serious gaps mentioned in the literature include the lack of studies about leftover spaces outside the USA and Europe, as well as the scarcity of studies on community wellbeing, small urban spaces, integrated infrastructures, abandoned structures, and a framework for intervention. Key themes emerging from the literature include social and ecological approaches in resilience; environmental stewardship, difficulties in knowledge participation for realizing leftover space potential; and the differing perception and participation of residents in landscape spaces that may lead to gentrification and urban decline. Key methods used include case study, literature review, and descriptive-analytical methods, but participatory, discourse analysis, LTM, DSS, and behavior mapping remain scarce.

Given the ambiguity, informality, and the fragmented nature of urban landscapes, a large number of such spaces are probable to occur within cities. This limited understanding of human perception in terms of landscape preference on leftover spaces is reflected in the trends we found in the literature.

Various theories on the preference of different ages, gender, culture, professionals and non-professionals, residents of different places, etc. could be considered for analyzing these spaces. Since preference could create a significant interaction between the citizens and the environment, it could have a specific role in landscape preference and interpretation of urban intervention in informal spaces. 
Although socio-ecological aspects are the most effective, serious gaps in the literature include the lack of studies about considering aesthetical and ecological qualities in leftover spaces that are formed by visual, sensorial (hearing, touch, smell, taste) and cognitive perception. Therefore the gaps in the literature (considering both socio-ecological and aesthetical aspects) on undefined lands suggests that it is important to understand the potential effects of repurposing citizen's ideas about both short- and long-term interventions in which to use those spaces.
This study focused on the generation of vacancy and the interim use of undefined lands as an opportunity and a flexible method of regeneration. Despite having a common approach to inventories or classifications, vacancy cannot be addressed through a 'one-size-fitsall' approach. Likewise, these spaces should never be read from a single perspective, as a combination of different criteria and multiple lenses determine an initial framework to the perception and represent the specific characteristic of undefined spaces.

\section{Reference}

1. Accordino, J., Johnson, G. T. Addressing the vacant and abandoned property problem. Journal of Urban Affairs, 2000, No. 22, p. 301-315.

2. Alexander, F., Powell, L. Neighborhood stabilization strategies for vacant and abandoned properties. Zoning and Planning Law Report, 2011, No. 34, p. 1-12.

3. Anderson, E. C., Minor, E. S. Vacant lots: An underexplored resource for ecological and social benefits in cities. Urban Forestry and Urban Greening, 2017, No. 21, p. 146-152.

4. Anuar, M. I. N. M., Ahmad, R. Exploring possible usage for elevated highway interstitial spaces: A case study of Duke and Akleh, Kuala Lumpur. Planning Malaysia, 2018, No. 16(3), p. 208-220.

5. Aruninta, A. WiMBY: A comparative interests analysis of the heterogeneity of redevelopment of publicly owned vacant land. Landscape and Urban Planning, 2009, No. 93(1), p. 38-45.

6. Berwyn, E. Mind the gap: Creating opportunities from empty space. Journal of Urban Regeneration and Renewal, 2013, No. 6(2), p. $148-153$.

7. Bowman, A. O., Pagano, M. A. Terra Incognita vacant land and urban strategies. Washington, D.C: Georgetown University Press, 2004.

8. Burkholder, S. The New Ecology of Vacancy: Rethinking Land Use in Shrinking Cities. Sustainability, 2012, No. 4(6), p. $1154-1172$.

9. Cadenasso, M. L., Pickett, S. T. A., Schwarz, K. Spatial heterogeneity in urban ecosystems: reconceptualizing land cover and a framework for classification. Frontiers in Ecology and the Environment, 2007, No. 5(2), p. 80-88.

10. De Sousa, C. A. Turning brownfields into green space in the City of Toronto. Landscape and urban planning, 2003, No. 62(4), p. $181-198$.

11. Desimini, J. From planned shrinkage to formerly urban: Staking landscape architecture's claim in the shrinking city debate. Landscape Journal, 2014, No. 33, p. 17-35.

12. Desimini, J. Limitations of the temporary: Landscape and abandonment. Journal of Urban History, 2015, 41(2), p. $279-293$.

13. Doron, G. M. The 'dead zone' and the architecture of transgression. City, 2016, No. 4(2), p. 247-263.

14. Fields, W. Urban Landscape Change in New Orleans, LA: The Case of the Lost Neighborhood of Louis. Unpublished doctoral dissertation. University of New Orleans, LA, 2005.

15. Folke, C. Resilience: the emergence of a perspective for social-ecological systems analyses. Global Environmental Change, 2006, No. 16(3), p. 253-267.

16. Franck, K. A., Stevens, Q. Loose space Possibility and Diversity in Urban Life. New York: Routledge, 2007.

17. Gandy, M. Unintentional landscapes. Landscape Research, 2016, No. 6397, p. 1-8.

18. Garvin, E. C., Cannuscio, C. C., Branas, C. C. Greening vacant lots to reduce violent crime: a randomised controlled trial. Injury Prevention, 2013, No. 19, p. 198-203.

19. Garvin, E., Branas, C., Keddem, S., Sellman, J., Cannuscio, C. More than just an eyesore: Local insights and solutions on vacant land and urban health. Journal of Urban Health, 2012, No. 90(3), p. 412-426.

20. Gibbs, G. Analyzing Qualitative Data. London: SAGE, 2018.

21. Girot, C. Vers une nouvelle nature. In: Landscape architecture in mutation: Essays on urban landscapes. Adam, H., École polytechnique fédérale. Zürich: GTA Verlag, 2005, p. 18-33.

22. Gottdiener, M., Hutchison, R. The New Urban Sociology 2nd edition. Boulder, CO: Westview Press, 2000.

23. Hollander, J. Sunburnt cities: The great recession, depopulation, and urban planning in the American sunbelt. New York, NY: Routledge, 2011.

24. Hollander, J. B., Pallagst, K., Schwarz, T., Popper, F. J. Shrinking cities as an emerging planning paradigm. Progress in Planning, Special Issue on Emerging Research Agendas in Urban design and planning, 2009, No. 72, p. 223-232.

25. Hollander, J. B., Németh, J. The bounds of smart decline: A foundational theory for planning shrinking cities. Housing Policy Debate, 2011, No. 21(3), p. 349-367.

26. Holling, C. S. Understanding the complexity of economic, ecological, and social systems. Ecosystems, 2001, No. 4(5), p. $390-405$.

27. Jacobs, J. The Death and Life of Great American Cities. New York, NY: Random House, 1961.

28. Johnson, M. P., Hollander, J., Hallulli, A. Maintain, demolish, repurpose: Policy design for vacant land management using decision models. Cities, 2014, No. 40, p. 151-162.

29. Krier, R. Urban Space. New York, NY: Rizolli International Publications, Inc., 1979.

30. Kitchenham, B., Charters, S. Guidelines for Performing Systematic Literature Reviews in Software Engineering. Durhum, UK: Keele University and Durham University, 2007.

31. Kim, G. The Public Value of Urban Vacant Land: Social Responses and Ecological Value. Sustainability (Switzerland), 2016, No. 8(5), p. 486-505. 
32. Kim, G. An integrated system of urban green infrastructure on different types of vacant land to provide multiple benefits for local communities. Sustainable cities and society, 2018, No. 36, p. 116-130.

33. Kim, G., Miller, P. A., Nowak, D. J. Assessing urban vacant land ecosystem services: Urban vacant land as green infrastructure in the City of Roanoke, Virginia. Urban Forestry \& Urban Greening, 2015, No. 14(3), p. 519-526.

34. Kim, G., Miller, P. A., Nowak, D. The Value of Green Infrastructure on Vacant and Residential Land in Roanoke, Virginia. Sustainability, 2016, No. 8(4), p. 296-311.

35. Kim, G, Miller, P. A., Nowak, D. J. Urban vacant land typology: A tool for managing urban vacant land. Sustainable Cities and Society, 2018, No. 36, p. 144-156.

36. Kim, M., Kim, G. Typology of Urban Left-Over Space. In: Proceedings of CELA Annual Meeting. University of Illinois, Urbana, Champaign, Il., 2012.

37. Kim, G., Newman, G., Jiang, B. Urban regeneration: Community engagement process for vacant land in declining cities. Cities, 2020, No. 102.

38. Kremer, P., Hamstead, Z. A., McPhearson, T. A social-ecological assessment of vacant lots in New York City. Landscape and Urban Planning, 2013, No. 120, p. 218-233.

39. Lee, J., Newman, G., Park, Y. A Comparison of Vacancy Dynamics between Growing and Shrinking Cities Using the Land Transformation Model. Sustainability, 2018, No. 10(5), p. 1-17.

40. Lefebvre, H., Nicholson, S., Harvey, D. The Production of Space. Oxford, UK: Blackwell Publishers, 1991.

41. Li, W., Zhou, W., Bai, Y., Pickett, S. T. A., Han, L. The smart growth of Chinese cities: Opportunities offered by vacant land. Land Degradation and Development, 2018, No. 29(10), p. 3512-3520.

42. LIN, Y. Identifying perceptions of the creative class regarding lost space in downtown Dallas. Unpublished master's thesis. The University of Texas at Arlington, TX, 2012.

43. Lokman, K. Vacancy as a laboratory: design criteria for reimagining social-ecological systems on vacant urban lands. Landscape Research, 2017, No. 6397(August), p. 1-19.

44. Loures, L., Panagopoulos, T., Burley, J. B. Assessing user preferences on post-industrial redevelopment. Environment and Planning B: Planning and Design, 2016, No. 43(5), p. 871-892.

45. Luo, S., \& Wit, S. De. Unlocking Interstices Multiple lenses enriching the participatory design of urban leftover spaces. In: Proceedings of the ECLAS Conference Ghent. Ghent, Belgium, 2018.

46. Machlis, G., Force, J. E., Burch, W. The human ecosystem. Part I: The human ecosystem as an organizing concept in ecosystem management. Society Natural Resources, 1997, No. 10(4), p. 347-367,

47. Madanipour, A. Ephemeral landscape and urban shrinkage. Landscape Research, 2017, No. 42(7), p. 1-11.

48. Madanipour, A. Temporary use of space: Urban processes between flexibility, opportunity and precarity. Urban Studies, 2018a, No. 55(5), p. 1093-1110.

49. Madanipour, A. Temporary use of space: Urban processes between flexibility, opportunity and precarity. Urban Studies, 2018b, No. 55(5), p. 1093-1110.

50. Mahmoudi Farahani, L., Maller, C. Investigating the benefits of 'leftover' places: Residents' use and perceptions of an informal greenspace in Melbourne. Urban Forestry and Urban Greening, 2019, No. 41, p. 292-302.

51. Millington, N. From urban scar to 'park in the sky': terrain vague, urban design, and the remaking of New York City's High Line Park. Environment and Planning A: Economy and Space, 2015, No. 47(11), p. 2324-2338.

52. Nassauer, J. I., Raskin, J. Urban vacancy and land use legacies: A frontier for urban ecological research, design, and planning. Landscape and Urban Planning, 2014, No. 125(SI), p. 245-253.

53. Nemeth, J., Hollander, J. Right-sizing shrinking cities: a landscape and design strategy for abandoned properties. Journal of Landscape Architecture, 2016, No. 11(2), p. 90-100.

54. Németh, J., Langhorst, J. Rethinking urban transformation: Temporary uses for vacant land. Cities, 2014, No. 40, p. $143-150$.

55. Newman, G., Gu, D., Kim, J.-H., Bowman, A. O. M., Li, W. Elasticity and urban vacancy: A longitudinal comparison of US cities. Cities, 2016, No. 58, p.143-151.

56. Newman, G., Kim, B. Urban shrapnel: spatial distribution of non-productive space. Landscape research, 2017, No. 42(7, SI), p. 699-715.

57. Newman, G., Lee, J., Berke, P. Using the land transformation model to forecast vacant land. Journal of Land Use Science, 2016, No. 11(4), p. 450-475.

58. Newman, G., Park, Y., Bowman, A. O. M., Lee, R. J. Vacant urban areas: Causes and interconnected factors. Cities, 2018, No. 72(B), p. 421-429.

59. Newman, G., Smith, A. L., Brody, S. D. Repurposing vacant land through landscape connectivity. Landscape Journal, 2017, No. 36(1), 37-57.

60. Newman, G., Bowman, A. O., Lee, R. J., Kim, B. A current inventory of vacant urban land in America. Journal of urban design, 2016, No. 21(3), p.302-319.

61. Nijhuis, S. GIS-based Landscape Design Research : Exploring Aspects of Visibility in Landscape Architectonic Compositions. In: Geodesign by Integrating Design and Geospatial Sciences. Lee, D. J., Dias, E., Scholten, H. (Eds.). Berlin: Springer, 2014, p. 193217.

62. Pallagst, K., Fleschurz, R., Trapp, F. Greening the shrinking city—policies and planning approaches in the USA with the example of Flint, Michigan. Landscape Research, 2017, No. 42(7), p. 716-727.

63. Pearsall, H., Lucas, S. Vacant land: The new urban green? Cities, 2014, No. 40, p. 121-123.

64. Pediaditi, K., Doick, K. J., Moffat, A. J. Monitoring and evaluation practice for brownfield, regeneration to greenspace initiations: A meta-evaluation of assessment and monitoring tools. Landscape and Urban Planning, 2010, 97(1), p. 22-36.

65. Peterson, G. Political ecology and ecological resilience: an integration of human and ecological dynamics. Ecological Economics, 2000, No. 35, p. 323-336.

66. Pickering, C., Byrne, J. The benefits of publishing systematic quantitative literature reviews for PhD candidates and other earlycareer researchers. Higher Education Research and Development, 2013, 3 No. 3(3), p. 534-548. 
67. Pickett, S. T. A., Grove, J. M., Nilon, C. H., Pouyat, R. V., Zipperer, W. C., Costanza, R. Urban ecological systems: linking terrestrial ecological, physical, and socioeconomic components of metropolitan areas. (Statistical Data Included). Annual Review of Ecology and Systematics, 2001, No. 32, p. 127-157.

68. Pickett, S. T. A., Cadenasso, M. L., Grove, M. J. Resilient cities: meaning, models, and metaphor for integrating the ecological, socio-economic, and planning realms. Landscape and Urban Planning, 2004, No. 69, p. 369-384.

69. Pickett, S. T. A., Belt, K. T., Galvin, M. F., Groffman, P. M., Grove, J. M., Outen, D.C., Pouyat, R.V, ... Cadenasso, M. L. Watersheds in Baltimore, Maryland: understanding and application of integrated ecological and social processes. Journal of Contemporary Water Research \& Education, 2007, No. 136, p. 44-55.

70. Ruelle, C., Halleux, J.-M.,Teller, J. Landscape quality and brownfield regeneration: a community investigation approach inspired by landscape preference studies. Landscape Research, 2012, No. 38, p. 75-99.

71. Rupprecht, C. D. D., Byrne, J. A. Informal urban green space: A typology and trilingual systematic review of its role for urban residents and trends in the literature. Urban Forestry and Urban Greening, 2014, No. 13(4), p. 597-611.

72. Sanches, P. M., Pellegrino, P. R. M. Greening potential of derelict and vacant lands in urban areas. Urban Forestry and Urban Greening, 2016, No. 19, p.128-139.

73. Schilling, J., Logan, J. Greening the rust belt: A green infrastructure model for right sizing America's shrinking cities. Journal of the American Planning Association, 2008, No. 74(4), p. 451-466.

74. Schilling, J. M., Mallach, A. Cities in transition: A guide for practicing planners. Washington, DC: American Planning Association, 2012.

75. Shemirani, M., Mofrad, S. Planning An essay on accessing the brownfields redevelopment roadmap appropriate with Iran's condition. International Journal of Architectural Engineering \& Urban Planning, 2015, No. 25(1).

76. Sperandelli, D. I., Dupas, F. A., Pons, N. A. D. Dynamics of urban sprawl, vacant land, and green spaces on the metropolitan fringe of São Paulo, Brazil. Journal of Urban Planning and Development, 2013, No. 139(4), p. 274-279.

77. Steele, J. How 'meanwhile' came to the high street. Journal of Urban Regeneration and Renewal, 2013, No. 6(2), p. $172-175$.

78. Stewart, W. P., Gobster, P. H., Rigolon, A., Strauser, J., Williams, D. A., van Riper, C. J. Resident-led beautification of vacant lots that connects place to community. Landscape and urban planning, 2019, No. 185, p. 200-209.

79. Sutton, S., Kemp, S. The Paradox of urban space: Inequality and transformation in marginalized communities. New York, NY: Palgrave MacMillan, 2011.

80. Threlfall, C. G., Kendal, D. The distinct ecological and social roles that wild spaces play in urban ecosystems. Urban Forestry \& Urban Greening, 2017, No. 29, p. 348-356.

81. Torres, A. C., Prevot, A.-C., Nadot, S. Small but powerful: The importance of French community gardens for residents. Landscape and urban planning, 2018, No. 180, p. 5-14.

82. Trancik, R. Finding lost space. New York: Routledge Taylor \& Francis Group, 1986.

83. Unt, A.-L., Bell, S. The impact of small-scale design interventions on the behaviour patterns of the users of an urban wasteland. Urban Forestry \& Urban Greening, 2014, No. 13(1), p. 121-135.

84. Walker, B. H., Anderies, J. M., Kinzig, A. P., Ryan, P. Exploring resilience in social-ecological systems through comparative studies and theory development: introduction to the special issue. Ecology and Society, 2006, No. 11(1): 12.

85. Wikström, T. Ordnade rum, impediment och marginell rumslighet - om plats och identitet $i$ det nya stadslandskape. Paper to Nordiskt seminarium om urban- och boendeforskning Helsinki. Helsinki, 17-19 November, 2002.

86. Wikström, T. Connecting the Suburban Landscape - The significance of informal footpaths in Flemingsberg, Sweden. Paper presented at Cities for People Conference. Copenhagen, June 9-11, 2004.

87. Wikström, T. Residual space and transgressive spatial practices - the uses and meanings of un-formed space. Nordisk arkitekturforskning, 2005, No. 18(1), 47-68.

88. Zhang, L., Klenosky, D. B. Residents' perceptions and attitudes toward waste treatment facility sites and their possible conversion: A literature review. Urban Forestry and Urban Greening, 2016, No. 20, p. 32-42.

89. Zhang, Z, Meerow, S., Newell, J. P., Lindquist, M. Enhancing landscape connectivity through multifunctional green infrastructure corridor modeling and design. Urban Forestry and Urban Greening, 2019, No. 38, p. 305-317.

90. Zhang, Zhenzhen, Meerow, S., Newell, J. P., Lindquist, M. Enhancing landscape connectivity through multifunctional green infrastructure corridor modeling and design. Urban Forestry and Urban Greening, 2019, No. 38(October 2018), p. $305-317$.

AUTHORS:

Maryam Naghibi, School of Architecture and Environmental Design, Iran University of Science and Technology (IUST). E-mail: maryam_naghibi@arch.iust.ac.ir

Mohsen Faizi, School of Architecture and Environmental Design, Iran University of Science and Technology (IUST).E-mail: mfaizi@iust.ac.ir

Ahmad Ekhlassi, School of Architecture and Environmental Design, Iran University of Science and Technology (IUST). E-mail: ekhlassi@iust.ac.ir

Kopsavilkums. Pētījumā uzsvars tiek likts uz ainavtelpas teritorijām, kas atstātas novārtā un veido telpiskos pārtraukumus. Rakstā sistematizēti un analizēti 65 recenzējamie dokumenti, atbilstošas tendences, atrašanās vietas, metodes, autori un biežāk pētītie aspekti. Pētījumā konstatēts, ka trūkst oficiālas nenoteiktas zemes definīcijas, līdz ar to pētījumā tiek izvirzīts nedefinētu zemju atslēgvārdu, definīciju izvērtējums un izpēte. 